\title{
Perilaku Caring Perawat Berdasarkan Teori Jean Watson di Ruang Rawat Inap
}

\author{
Cecep Solehudin Firmansyah ${ }^{1}$, Richa Noprianty², Indra Karana ${ }^{3}$ \\ Prodi Sarjana Keperawatan, Sekolah Tinggi Ilmu Kesehatan Dharma Husada, Bandung, 1,2,3 \\ richanoprianty@stikesdhb.ac.id ${ }^{2}$
}

Submitted 15 November 2018 Revised 12 Januari 2019 Accepted 22 Januari 2019

\section{ABSTRAK}

Latar Belakang: Caring merupakan bentuk kepedulian perawat terhadap klien sebagai bentuk perhatian, penghargaan dan mampu memenuhi kebutuhannya. Fenemona yang ada empat dari lima klien yang diwawancarai menyebutkan perawat kurang caring terhadap klien. Kurang caring-nya perawat ditandai dengan kurang pedulinya perawat terhadap klien, sehingga klien mengeluh bahwa perawat pada ruangan tersebut kurang memperhatikan kenyamanan klien.

Tujuan: Penelitian ini bertujuan untuk mengetahui Perilaku Caring Perawat Berdasarkan Teori Jean Watson di Ruang Rawat Inap RSAU DR. M. Salamun Bandung.

Metode: Jenis penelitian kuantitatif dengan pendekatan survey deskriptif. Sampel yang digunakan adalah Pasien rawat inap minimal lama rawat 3 hari dengan teknik total sampling yaitu 142 orang. Pengumpulan data menggunakan data primer dengan instrumen penelitian yaitu kuesioner Behaviors Assessment Caring dari sepuluh carative faktor Jean Watson. Analisis data berupa distribusifrekuensi.

Hasil: Hasil penelitian tentang perilaku caring perawat 52,1\% yaitu cukup, Pemenuhan kebutuhan manusia 73,2\%, Sistem Nilai Humanistik Altruistik $43,7 \%$, Keyakinan dan harapan klien 47,9\%, Kepekaan terhadap diri sendiri dan orang lain $50,0 \%$, Hubungan membantu rasa percaya $48,6 \%$, penerima ungkapan positif dan negatif $51,4 \%$, Metode pemecahan masalah $47,2 \%$, Proses pengajaran interpersonal 45,1\%, Lingkungan psikologis $60,6 \%$ perilaku caring perawat cukup dan Kekuatan eksistensial fenomenologis klien menilai $44,4 \%$ perilaku caring perawat yaitu baik.

Kesimpulan: Klien menilai perilaku caring perawat memiliki kategori cukup, Oleh karena itu karena itu bagi rumah sakit untuk membuat program pelatihan tentang caring bagi perawat agar perilaku caring perawat menjadi lebih baik. .

Kata Kunci: caring; Jean Watson; perilaku

\section{ABSTRACT}

Background: Caring is a nurse's concern to clients was form of attention, appreciation and able was meet their needs. Phenomenon who had four out of five clients interviewed mentioned nurses less caring for clients. Objective: Less caring her nurses marked with less caring nurses to clients, so clients complain that the nurses in the room less attention to the convenience of clients.

Methods: The type was of quantitative research with descriptive survey approach. The sample used was inpatient minimum patient duration of 3 days with total sampling technique was is 142 people. Data collection of primary data with research instrument that is questionnaire Behaviors Assessment Caring was of ten carative factor Jean Watson. Data analysis is frequency distribution.
Results: Result of research on caring behavior of nurse $52,1 \%$ that was enough, fulfillment of human need $73,2 \%$, Altruistic Humanistic Value System 43,7\%, Confidence and expectation of client $47,9 \%$, Sensitivity to self and others 50,0\% , Relationship helps confidence 48,6\%, recipient of positive and negative expression 51,4\%, Problem solving method 47,2\%, Interpersonal teaching process 45,1\%, Psychological environment 60,6\% sufficient nurse caring behavior and phenomenological existential power client assess $44,4 \%$ caring behavior of nurse that is good.

Conclusion: It is concluded that the client assess the caring behavior of the nurses have enough category, therefore therefore for the hospital can evaluate about caring conducted by nurses in RSAU DR. M. Salamun Bandung.

Keywords: anjungan mandiri posyandu; policy; mobile apps 


\section{PENDAHULUAN}

Kemajuan teknologi di berbagai bidang telah memberikan banyak dampak bagi kehidupan manusia salah satunya peningkatan masalah kesehatan yang berdampak pada status kesehatan masyarakat. Hal ini mendorong peningkatan kebutuhan akan pelayanan kesehatan, yang salah satunya adalah pelayanan keperawatan. Keperawatan merupakan bagian dari sistem pelayanan kesehatan yang berhubungan dengan manusia, dan memberikan pelayanan komprehensif terhadap seluruh aspek kehidupan yaitu biopsiko-sosial dan spiritual (Nursalam, 2014)

Pelayanan keperawatan merupakan bentuk pelayanan kesehatan yang unik dan berbeda dengan pelayanan kesehatan yang diberikan oleh dokter ataupun profesi lain. Filosofi dari keperawatan adalah humanisme, holism dan care (Nursalam, 2014). Keperawatan merupakan profesi yang mengedepankan sikap "care", atau kepedulian, dan kasih sayang terhadap klien. (Perry, 2012).

(Watson, 2009) menempatkan caring sebagai dasar dan sentral dalam praktek keperawatan. Caring memberikan kemampuan pada perawat untuk memahami dan menolong klien. Seorang perawat harus memiliki kesadaran tentang asuhan keperawatan, dalam memberikan bantuan bagi klien dalam mencapai atau mempertahankan kesehatan atau mencapai kematian dengan damai Linberg, dalam (Nursalam, 2014).

Penelitian Aiken (2012) menunjukkan persentase perawat yang memiliki kualitas pelayanan caring yang buruk terdapat pada Negara Irlandia 11\%, dan Yunani 47\%. International Association of Human Caring menjelaskan bahwa keperawatan selalu meliputi empat konsep yaitu merawat adalah apa yang perawat lakukan, manusia adalah sasaran dari apa yang perawat lakukan, kesehatan adalah tujuannya dan lingkungan adalah tempat dimana perawat merawat.

Di Indonesia sendiri caring menjadi salah satu penilaian bagi para pengguna pelayanan kesehatan. Berdasarkan hasil survei kepuasan klien pada beberapa Rumah Sakit di Jakarta menunjukan bahwa 14\% klien tidak puas terhadap pelayanan kesehatan yang diberikan, disebabkan oleh perilaku caring kurang baik (Kemenkes RI, dalam Abdul, 2015).

Perilaku yang ditampilkan oleh perawat adalah dengan memberikan rasa nyaman, perhatian, kasih sayang, peduli, pemeliharaan kesehatan, memberi dorongan, empati, minat, cinta, percaya, melindungi, kehadiran, mendukung, memberi sentuhan dan siap membantu serta mengunjungi klien (Watson, 2012). Perilaku seperti itu akan mendorong klien dalam perubahan aspek fisik, psikologis, spiritual, dan sosial kearah yang lebih baik.

Watson (2012) dalam Theory of Human Care mengungkapkan bahwa ada sepuluh carative factor yang dapat mencerminkan perilaku caring dari seorang perawat. Sepuluh faktor tersebut adalah membentuk sistem nilai humanistik-altruistik, menanamkan keyakinan dan harapan, mengembangkan sensitivitas untuk diri sendiri dan orang lain, membina hubungan saling percaya dan saling membantu, meningkatkan dan menerima ekspresi perasaan positif dan negatif, menggunakan metode pemecahan masalah yang sistematis dalam pengambilan keputusan, meningkatkan proses belajar mengajar interpersonal, menyediakan lingkungan yang mendukung, melindungi, dan atau memperbaiki mental, sosiokultural dan spiritual, membantu dalam pemenuhan kebutuhan dasar manusia, mengembangkan faktor kekuatan eksistensial fenomenologis.

Penelitian terdahulu yang dilakukan oleh Fikri (2017) di RSAU DR. M. Salamun Bandung menunjukkan hasil $77 \%$ perilaku afektif kurang dan masih ada perilaku caring buruk. Hal tersebut karena observasi perawat merupakan peran yang baik bagi persepsi pasien itu sendiri dengan dilakukan observasi terhadap pasien pemilihan di rumah sakit RSAUDR. M. Salamun Bandung

Berdasarkan studi pendahuluan di RSAU DR. M. Salamun Bandung bahwa pelayanan perawatan memiliki dua jenis pelayanan yaitu 
pelayanan Rawat jalan dan pelayanan Rawat inap. Peneliti mengambil tempat penelitian di pelayanan Rawat Inap yaitu di ruang Rajawali dan Gelatik. Berdasarkan observasi awal bahwa perawat dituntut untuk mampu memberikan pelayanan yang maksimal salah satunya dapat dilihat dari perilaku caring perawat terhadap klien dalam pemberian asuhan keperawatan.

Hasil observasi awal diketahui empat dari lima klien yang diwawancarai menyebutkan perawat kurang caring terhadap klien ditandai dengan kurang pedulinya perawat terhadap klien, sehingga klien mengeluh bahwa perawat pada ruangan tersebut kurang memperhatikan kenyamanan klien, tidak pernah memberikan sentuhan dan kurangnya penjelasan dari perawat terkait prosedur dan tindakan yang akan dilakukan. Selain itu pembagian tugas perawat tidak berjalan dengan baik serta jarang memberikan pujian dan sentuhan pada klien.

Memperkuat fenomena penelitian ini kemudian peneliti melakukan wawancara kepada klien di ruang Gelatik dan Rajawali. Berdasarkan survey data awal menemukan dua dari sepuluh klien yang diwawancarai mengatakan bahwa perawat kurang terbuka terhadap klien dan kurang memberikan kasih sayang, sehingga perawat jarang komunikasi antara peribadi perawat-klien. Selain itu perawat kurang membantu klien ke toilet untuk BAK/BAB sedangkan klien butuh kehadiran perawat untuk membatu klien dalam mobilitasnya dikarenakan keterbatasan klien dalam beraktifitas yang disebabkan kondisi yang dialaminya.

Selain itu dua klien menyatakan perawat kurang memberikan penjelasan kepada klien tentang penyakit yang dialaminya, sehingga keyakinan dan harapan klien kurang terjalin dengan harmonis antara perawat-klien.

Sedangkan enam dari sepuluh klien menyatakan perawat kurang memahami dengan apa yang dirasakan kondisi klien saat ini, sehingga jalinan hubungan kepercayaan diri antara perawat-klien masih kurang.
Selanjutnya perawat belum mampu menunjukkan kesiapan dalam mengambil risiko, seperti perawat belum memahami perasaan klien, sehingga perawat kurang merasa khawatir dengan klien yang berhubungan dengan penyakitnya atau perawat kurang perilaku dalam penerimaan ungkapan perasaan positif-negatif terhadap klien.

Berdasarkan fenomena dan latar belakang diatas bahwa kurangnya perilaku caring perawat terhadap klien dalam memberikan asuhan keperawatan, maka urian dan paparan diatas peneliti tertarik untuk melakukan penelitian tentang Perilaku Caring Perawat Berdasarkan Teori Jean Watson Di Ruang Rawat Inap RSAU DR. M. Salamun Bandung.

\section{METODE}

Jenis penelitian yang digunakan adalah deskriptif kuantitatif dengan pendekatan survey deskriptif. Populasi dalam penelitian ini adalah seluruh klien periode bulan Juni 2018 yang ada di ruangan 2 ruangan yaitu Gelatik sebanyak 70 orang dan Rajawali sebanyak 72 orang, sehingga jumlah populasi dalam penelitian ini yaitu sebanyak 142 orang.

Teknik pengambilan sampel dalam penelitian ini adalah menggunakan tehnik total sampling. Instrumen penelitian adalah alat-alat yang digunakan untuk pengumpulan data. Kuesioner yang diunakan pada ini dilihat berdasarkan Caring Behaviors Assessment (CBA) Tools yang terdiri dari 63 pernyataan positif berdasarkan teori caring dan sepuluh carative factor menurut teori Watson (2012).

Kuesioner ini telah melalui proses penterjemahan ke dalam bentuk bahasa Indonesia yang dikutip dari penelitian Tumaggor (2013). CBA terdiri dari 63 perilaku Caring perawat yang dikelompokkan menjadi subskala yang disesuaikan 10 faktor karatif Watson. Alat ukur ini menggunakan skala Likert (5 poin) yang merefleksikan perilaku Caring perawat yaitu $5=$ sangat penting, $4=$ penting, $3=$ sedikit penting, $2=$ tidak penting, 
$1=$ sangat tidak penting.

Uji validitas telah diuji oleh Manogin, Bechtel, dan Rami dalam Watson, 2012) menggunakan CBA hasil uji validitas dalam tiap subskala berkisar dari 0,66 sampai 0. 90, sedangkan hasil uji reabilitas menunjukkan sebesar 0.93 yang berarti sudah layak untuk melakukan penelitian.

\section{HASIL DAN PEMBAHASAN}

\section{Tabel 4.1 Perilaku caring perawat}

\begin{tabular}{|c|c|c|}
\hline Perilaku caring & Frekuensi & Persentase \\
\hline Baik & 17 & 12.0 \\
\hline Baik & 74 & 52.1 \\
\hline Baik & 51 & 35.9 \\
\hline Total & 142 & 100.0 \\
\hline
\end{tabular}

Berdasarkan tabel 4.1 dapat diketahui 52,1\% klien menilai perilaku caring perawat cukup. Adapun caring perawat diukur berdasarkan 10 faktor caratif Jean Watson.

Tabel 4. 2 Gambaran Perilaku caring perawat berdasarkan Jean Watson

\begin{tabular}{|c|c|c|c|c|c|c|}
\hline \multirow{2}{*}{ Perilaku caring } & \multicolumn{2}{|c|}{ Baik } & \multicolumn{2}{|c|}{ Cukup } & \multicolumn{2}{|c|}{ Kurang } \\
\hline & f & $\%$ & f & $\%$ & f & $\%$ \\
\hline $\begin{array}{l}\text { 1. Sistem Nilai Humanistik } \\
\text { Altruistik }\end{array}$ & 56 & 39,4 & 62 & 43,7 & 24 & 16,9 \\
\hline 2. Keyakinan dan harapan & 60 & 42,3 & 86 & 47,9 & 14 & 9,9 \\
\hline $\begin{array}{l}\text { 3. Kepekaan terhadap diri } \\
\text { sendiri dan orang lain }\end{array}$ & 58 & 40,8 & 71 & 50,0 & 13 & 9,2 \\
\hline $\begin{array}{l}\text { 4. Hubungan membantu } \\
\text { rasa percaya }\end{array}$ & 64 & 45,1 & 69 & 48,6 & 9 & 6,3 \\
\hline $\begin{array}{l}\text { 5. Perilaku penerima } \\
\text { ungkapan perasaan } \\
\text { positif dan negative }\end{array}$ & 58 & 40,8 & 73 & 51,4 & 11 & 7,7 \\
\hline $\begin{array}{l}\text { 6. Metode pemecahan } \\
\text { masalah pada klien }\end{array}$ & 52 & 36,6 & 67 & 47,2 & 23 & 16,2 \\
\hline $\begin{array}{l}\text { 7. Proses pengajaran } \\
\text { interpersonal }\end{array}$ & 62 & 43,7 & 64 & 45,1 & 16 & 11,3 \\
\hline 8. Lingkungan psikologis & 43 & 30,3 & 86 & 60,6 & 13 & 9,2 \\
\hline $\begin{array}{l}\text { 9. Pemenuhan kebutuhan } \\
\text { manusia pada klien }\end{array}$ & 104 & 73,2 & 31 & 21,8 & 7 & 4,9 \\
\hline $\begin{array}{l}\text { 10.Kekuatan eksistensial } \\
\text { fenomenologis }\end{array}$ & 63 & 44,4 & 60 & 42,3 & 19 & 13,4 \\
\hline
\end{tabular}

Berdasarkan tabel 4.2 dapat diketahui dari 142 klien yang menilai perilaku caring perawat didapatkan pada faktor Sistem Nilai Humanistik Altruistik klien menilai perilaku caring perawat cukup yaitu 43,7\%, Keyakinan dan harapan 47,9\% cukup, Kepekaan terhadap diri sendiri dan orang lain 50,0\% cukup, Hubungan membantu rasa percaya $48,6 \%$ cukup, Perilaku penerima ungkapan perasaan positif dan negatif $51,4 \%$, Metode pemecahan masalah pada klien $47,2 \%$ cukup, Proses pengajaran interpersonal $45,1 \%$ cukup, Lingkungan psikologis $60,6 \%$ cukup, Pemenuhan kebutuhan manusia pada klien yaitu $73,2 \%$ baik dan Kekuatan eksistensial fenomenologis menunjukkan $44,4 \%$ yaitu baik.

\section{A. Perilaku caring perawat di Ruang Rawat I nap}

Berdasarkan hasil penelitian menunjukkan perilaku caring perawat sebagian besar $52,1 \%$ klien menilai perilaku caring perawat cukup. Hal tersebut dipengaruhi oleh persepsi klien terhadap pandangan perawat, sehingga klien menilai perawat dalam perilaku caring masih cukup. Perilaku caring yang cukup dari pelayanan yang di berikan oleh perawat, klien akan cenderung memiliki persepsi yang baik terhadap perawat.

Caring dipersepsikan oleh klien sebagai ungkapan cinta dan ikatan, otoritas dan keberadaan, selalu bersama, empati, dapat memotivasi perawat untuk dapat lebih care pada klien dan mampu melakukan tindakan sesuai kebutuhan klien. Semakin baik perilaku caring perawat dalam memberikan pelayanan asuhan keperawatan, klien atau keluarga semakin senang dalam menerima pelayanan, berarti hubungan terapeutik perawat-klien semakin terbina.

Hal ini perawat yang memberikan caring terhadap klien yang berarti perawat sudah dapat menunjukkan perhatian, tanggung jawab atas perawatan yang diberikan terhadap klien, dan juga merawat klien dilakukan dengan tulus dan ikhlas.

Sejalan dengan hasil penelitian Fikri (2017) menunjukkan hasil 77\% perilaku afektif kurang dan masih ada perilaku caring buruk. Hal sama dengan hasil penelitian yang telah dilakukan oleh Tiara \& Lestari (2013) tentang Hubungan Antara Caring Perawat Dengan 
Tingkat Kepuasan Klien Rawat Inap Di Rumah Sakit Umum Daerah Pringsewu Lampung. Perawat dalam memberikan pelayanan (caring) terhadap klien mayoritas rendah yaitu sebanyak 54 responden (56,3\%) dan yang menilai pelayanan dengan caring yang tinggi sebanyak 42 responden (43,8\%). Nilai p : 0.007 artinya ada hubungan antara caring perawat dengan tingkat kepuasan klien di Ruang Rawat Inap RSUD Pringsewu. Perawat dalam memberikan pelayanan (caring) terhadap klien mayoritas rendah.

Perilaku caring merupakan manifestasi perhatian kepada orang lain, berpusat pada orang, menghormati harga diri dan kemanusiaan. Caring mempunyai komitmen untuk mencegah terjadinya sesuatu yang buruk, memberi perhatian dan konsen, menghormati orang lain dan kehidupan manusia. Caring juga merupakan ungkapan cinta dan ikatan, otoritas dan keberadaan, selalu bersama, empati, dapat memotivasi perawat untuk dapat lebih care pada klien dan mampu melakukan tindakan sesuai kebutuhan klien (Dwidiyanti, 2012).

Caring menurut Watson (2012) dikutip dari Potter \& Perry (2013) merupakan sentral praktek keperawatan dimana perawat bekerja untuk lebih meningkatkan kepeduliannya terhadap klien. Aspek utama caring dalam analisis meliputi : pengetahuan, penggantian irama (belajar dari pengalaman), kesabaran, kejujuran, rasa percaya, kerendahan hati harapan dan keberaniannya. memberi perhatian dan konsen, menghormati orang lain dan kehidupan manusia.

Dampak perilaku caring bagi klien adalah meningkatkan hubungan saling percaya, meningkatkan penyembuhan fisik, keamanan, memiliki banyak energi, biaya perawatan lebih rendah, serta menimbulkan perasaan lebih nyaman (Watson, 2012). Hasil penelitian Suryantini (2014) menunjukan hasil adanya hubungan yang positif antara perilaku caring perawat dengan kepuasan klien. Semakin baik caring perawat akan meningkatkan proporsi kepuasan klien terhadap pelayanan keperawatan. Kepuasan klien terhadap pelayanan keperawatan merupakan indikator penting dari kualitas pelayanan Rumah Sakit, karena sebagian besar pelayanan yang ada di rumah sakit diberikan oleh perawat (Laschinger, Gilbert \& Smith, 2011).

Penelitian tentang CBA yang dilakukan Hanan, et all (2013) menunjukkan hasil bahwa $(91,1 \%)$ klien merasa puas dengan perilaku caring yang dilakukan oleh perawat. Penilaian Perilaku skala (CBA) terdiri dari 63 item berdasarkan sepuluh faktor carative Watson (Tumanggor, 2013).

Menurut Mcdaniel dalam Watson (2012), perilaku caring mempunyai tiga hal yang tidak dapat dipisahkan yaitu perhatian, tanggung jawab, dan dilakukan dengan iklas. Sikap caring juga akan meningkatkan kepercayaan klien terhadap perawat dan mengurangi kecemasan klien. Kedua hal tersebut dapat memperkuat mekanisme koping klien sehingga memaksimalkan proses penyembuhaan. Kunci dari kualitas pelayanan asuhan keperawatan adalah perhatian, empati dan kepedulian perawat. Aktifitas yang Menunjukkan Caring Perawat.

\section{Sistem nilai humanistik altruistic}

Berdasarkan hasil penelitian menunjukkan perilaku caring perawat dilihat dari Sistem Nilai Humanistik Altruistik klien menilai perilaku caring perawat cukup yaitu $43,7 \%$. Hal tersebut dipengaruhi oleh sikap perawat yang kurang merespon terhadap tindakan yang diberikan terhadap klien, sehingga klien menggap bahwa perilaku caring cukup. Caring perawat cukup karena perawat sudah memberikan kebaikan dan kasih sayang serta membuka diri untuk melakukan tindakan terapi atau asuhan keperawatan dengan klien secara terbuka.

Hal ini dapat dilihat pada point pertanyaan pada pertanyaan No. 2 yaitu perawat tidak melihat dari berbagai hal sudut pandang klien, sehingga caring perawat kurang. Menurut Novieastari (2012), perilaku 
caring berfokus pada human science dan human care yang dilaksanakan dalam pembentukan nilai humanistic altruistik. Seorang klien yang pada masa sehat terbiasa hidup dengan pelayanan yang sepenuhnya dipusatkan pada pemuasan semua keinginan, tentu sewaktu mendapat perawatan akan menuntut perlakuan yang sesuai dengan yang diperolehnya dalam hidup sehari-hari.

Hasil ini tidak sejalan dengan hasil penelitian Desima (2010) tentang Tingkat Stres Kerja Dan Perilaku Caring Perawat. Hasil penelitianya menunjukkan perilaku caring tergolong kurang baik terjadi pada sekitar 18 $(14,35 \%)$ perawat. Perilaku caring yang kurang baik itu dipengaruhi adanya beban kerja yang terlalu banyak hal itu diperkuat dengan adanya keluhan perawat di Instalasi Rawat Inap Rumah Sakit Malang terhadap adanya beban kerja yang banyak, sehingga banyak keluhan klien di Instalasi Rawat Inap tentang keramahan, kesabaran, perhatian perawat yang masih kurang

Menurut Watson (2012) perawat yang mempunyai nilai-nilai humanistik dan altruistik dapat dilambangkan melalui penilaian terhadap pandangan diri seseorang, kepercayaan, interaksi dengan berbagai kebudayaan dan pengalaman pribadi. Melalui sistem nilai humanistik dan altruistik ini perawat menumbuhkan rasa puas karena mampu memberikan sesuatu pada klien. Selain itu, perawat juga memperlihatkan kemampuan diri dengan memberikan pendidikan kesehatan kepada klien. Pembentukan sistem nilai humanistik dan altruistik mulai berkembang diusia dini dengan nilai-nilai yang berasal dari orang tuanya. Sistem nilai ini pengalaman hidup buat seseorang dan mengantarkan ke arah kemanusiaan.

Pembentukan sistem nilai humainistikaltruistik dibangun dari pengalaman hidup, belajar dan juga dapat ditingkatkan selama masa pendidikan perawat. HumanistikAltruistik dapat didefinisikan sebagai kepuasan dalam memberi yang berasal dari dalam diri sendiri (Marriner \& Tomey, 2012). Sikap perawat yang mencerminkan nilai Humanistik-Altruistik ialah perawat memberikan kebaikan dan kasih sayang serta membuka diri untuk melakukan tindakan terapi dengan klien (Potter \& Perry, 2012).

\section{Keyakinan dan harapan}

Berdasarkan hasil penelitian menunjukkan perilaku caring perawat dilihat dari keyakinan dan harapan klien menilai perilaku caring perawat cukup yaitu $47,9 \%$. Hal ini perawat harus mampu mendorong klien untuk menemukan harapan. Keyakinan dan harapan disini menggambarkan faktor kreatif perawat yang akan tercipta perasaan lebih baik melalui kepercayaan dan atau keyakinan yang sangat berarti bagi seseorang secara individu yaitu klien. Perawat menanamkan keyakinan dan harapan berarti perawat menekankan pentingnya obat-obatan untuk curative, perawat juga perlu memberi tahu individu alternatif pengobatan lain yang tersedia (misal meditasi, relaksasi, atau kekuatan penyembuhan oleh diri sendiri atau secara spritual). Dengan mengembangkan hubungan perawat-klien yang efektif, perawat memfasilitasi perasaan optimis, harapan, dan rasa percaya.

Hal ini dapat dilihat pada point pertanyaan keyakinan dan harapan pada pertanyaan No. 6 yaitu perawat tidak mendorong klien untuk percaya diri artinya perawat kurang memberikan dukungan terhadap klien, sehingga klien memiliki pandangan yang kurang trehadap perilaku caring.

Hal ini berarti perawat yang ada sudah cukup dalam memberikan perilaku caring pada klien, seperti perilaku caring Perawat meyakinkan klien atas perkembangan kesehatan yang dirasakan saat ini, Perawat mendorong klien agar percaya diri, Perawat menunjukkan hal-hal positif terhadap klien dan kondisi klien, serta perawat sudah dapat memuji usaha-usaha yang klien lakukan dalam hal pengobatan. 
Penelitian Suliano, M \& Sari, R (2016) tentang hubungan perilaku caring perawat dengan keyakinan dan harapan klien kanker di Rumah Sakit. Hasil penelitianya menemukan dari jumlah 120 perawat yang diteliti, diperoleh $64,1 \%$ responden mempersepsikan perilaku caring perawat baik, $51,3 \%$ responden mempunyai keyakinan baik, dan $61,5 \%$ responden mempunyai harapan baik.

Potter \& Perry, (2012) menyatakan bahwa Perawat memberikan keyakinan/ kepercayaan dengan cara memfasilitasi dan meningkatkan asuhan keperawatan yang holistik. Dalam hubungan perawat klien yang efektif, perawat memfasilitasi perasaan optimis, harapan dan kepercayaan. Disamping itu, perawat meningkatkan Perilaku klien dalam mencari pertolongan kesehatan. Kepercayaan dan penghibur sangat penting bagi proses kreatif maupun kuratif. Dengan menggunakan faktor kreatif ini akan tercipta perasaan lebih baik melalui kepercayaan dan atau keyakinan yang sangat berarti bagi seseorang secara individu.

Hal sama dengan apa yang diungkapkan oleh Alligood \& Tomey, (2012) secara teori bahwa keyakinan dan harapan yaitu menggambarkan peran perawat dalam meningkatkan hubungan antara perawat-klien yang lebih efektif dalam meningkatkan kesehatan dan menolong klien beradaptasi dengan keadaan sehat sakit. Faktor ini merupakan gabungan dari nilai humanisticaltruistik dalam memfasilitasi promosi kesehatan melalui pemberian asuhan keperawatan secara holistik. Perawat harus mampu menjalin hubungan yang baik dengan klien, memperoleh informasi klien yang dibutuhkan selama merawat klien, dan perawat harus mampu mendorong klien untuk menemukan harapan.

\section{Kepekaan Terhadap Diri Sendiri dan Orang Lain}

Berdasarkan hasil penelitian menunjukkan perilaku caring perawat dilihat dari Kepekaan Terhadap Diri Sendiri dan orang lain klien menilai $50 \%$ perilaku caring perawat cukup. Hal tersebut berarti perawat sudah cukup dalam memahami klien, menghargai kepekaan perasaan klien sehingga perawat sendiri dapat menjadi lebih sensitif, murni dan bersikap wajar kepada orang lain terutama pada klien yang dirawatnya.

Hal ini dapat dilihat pada point pertanyaan kepekaan terhadap diri sendiri dan orang lain pertanyaan No. 9 yaitu perawat kurang memahami klien artinya perawat kurang memahami kondisi, perasaan dan suasana hati klien saat ini sehingga perawat memiliki perilaku caring kurang. Hal tersebut berarti perawat telah memahami kebutuhan klien, seperti menanyakan kepada klien yang dilakukan saat ini dan menerima klien apa adanya serta perawat peka terhadap perasaan dan suasana hati klien.

Sejalan dengan hasil penelitian Manurung \& Hutasoit (2013) tentang Persepsi Klien Terhadap Perilaku Caring Perawat di Ruang Rawat Inap Rumah Sakit. Hasil penelitiannya menunjukkan kebutuhan caring (nilai $\mathrm{p}=0,001$ ) dan perilaku caring perawat (nilai $\mathrm{p}=0,006$ ). Terpenuhinya kebutuhan caring dan perbaikan perilaku caring perawat akan menjadikan persepsi klien menjadi positif selama rawat inap.

Rego, Godinho, Mcqueen (2012) menyebutkan bahwa perawat belajar menghargai kepekaan atau kesensitifan dan perasaan klien sehingga ia sendiri dapat menjadi lebih sensitif, murni dan bersikap wajar kepada orang lain. Pengembangan kepekaan dengan diri dan orang lain, mengeksplorasi kebutuhan perawat untuk mulai merasakan suatu emosi yang muncul dengan sendirinya. Hal itu hanya dapat berkembang melalui perasaan diri seseorang yang pekadalam berintraksi dengan orang lain. Jika perawat berusaha untuk meningkatkan kepekaan dirinya, maka ia akan lebih autentik (tampil apa adanya). Autentik akan menambah pertumbuhan diri dan aktualisasi diri baik bagi perawat sendiri maupun bagi orang-orang yang berinteraksi dengan perawat itu

Perawat belajar meningkatkan kepekaan 
sehingga bisa menerima keberadaan diri sendiri dan orang lain. Adanya rasa sensitif dalam diri perawat, membuat perawat lebih ikhlas, lebih peka terhadap orang lain, dan tampil apa adanya. Perawat harus paham tentang kebutuhan psikologis dan spiritual klien, meningkatkan rasa kepekaan sehingga mampu menemukan cara untuk menunjukkan Caring padaklien (Alligood \& Tomey, 2012).

\section{Hubungan membantu rasa percaya}

Berdasarkan hasil penelitian menunjukkan perilaku caring perawat dilihat dari hubungan membantu rasa percaya klien menilai $48,6 \%$ perilaku caring perawat cukup. Hal tersebut hubungan saling percaya antara klien dan perawat sudah terjalin dengan baik dan kepercayaan perawat dapat menerapkan bentuk komunikasi untuk menjalin hubungan dalam keperawatan.

Hal ini dapat dilihat pada point pertanyaan hubungan membantu rasa percaya pertanyaan No. 14 yaitu Perawat kurang memahami dan perawat tidak membatasi pengunjung, sehingga klien kurang berisitirhat artinya kepedulian perawat terhadap klien masih kurang dan klien beranggapan perilaku caring perawat memiliki kategori cukup. Hal tersebut berarti perawat sudah dapat membantu klien dalam hal pemenuhan kebutuhan, seperti Perawat baik dan penuh perhatian terhadap klien, Perawat memahami dan membatasi pengunjung agar klien bisa beristirahat, serta perawat memperlakukan klien dengan hormat.

Hasil penelitian yang dilakukan oleh Juwariyah \& Joyo (2014) tentang hubungan perilaku caring perawat dengan tingkat kepuasan klien di Poli VCT RSUD Gambiran Kota Kediri Berdasarkan Teori Watson. Hasil penelitiannya menunjukkan perilaku caring perawat dalam kategori "care" yaitu 18 orang (36\%). Perawat merupakan bagian dari tim pelayanan kesehatan di rumah sakit, perilaku caring yang ditunjukkan perawat dalam memberikan pelayanannya menjadi salah satu indikator mutu pelayanan.
Menurut Cosette (2008) caring mencakup upaya perawat untuk meningkatkan proses pembelajaran interpersonal, menanamkan konsep self care, menumbuhkan hubungan saling membantu, menggunakan metode penyelesaian masalah dengan lebih kreatif, menghargai kekuatan - kekuatan yang ada dalam kehidupan, terbuka pada dimensi spiritual caring serta penyembuhan yang tidak dapat dijelaskan secara ilmiah, bertindak berdasarkan sistem nilai yang manusiawi, menanamkan harapan dan kepekaan terhadap diri sendiri atau orang lain serta memberikan kenyamanan kepada klien dalam bentuk memenuhi kebutuhan dasar klien dengan penuh penghargaan.

Wardhono (2012) menyatakan bahwa sebagai perawat professional, maka harus menciptakan hubungan saling percaya antara perawat dan klien adalah sangat kursial bagi transpersonal caring. Hubungan saling percaya akan meningkatkan dan menerima ekspresi perasaan positif dan negatif. Pengembangan hubungan saling percaya menerapkan bentuk komunikasi untuk menjalin hubungan dalam keperawatan. Karakteristik faktor ini adalah kongruen, empati dan ramah. Kongruen berarti perawat menanyakan apa adanya dalam berinteraksi dan tidak menyembunyikan kesalahan.

Perawat bertindak dengan cara yang lebih terbuka danjujur. Empati berarti perawat memahami apa yang dirasakan klien. Ramah berarti penerimaan positif terhadap orang lain yang sering diekspresikan dengan bahasa tubuh, ucapan tekanan orang lain yang sering diekspresikan dengan bahasa tubuh, ucapan tekanan suara, sikap terbuka, ekspresi wajah dan lain-lain.

\section{Penerima ungkapan perasaan positif dan negatif}

Berdasarkan hasil penelitian menunjukkan perilaku caring perawat dilihat dari Penerima ungkapan perasaan positif dan negatif klien menilai $51,4 \%$ perilaku caring perawat cukup. Hal tersebut perawat sudah 
dapat menerima ungkapan dan mendengarkan semua keluhan dan perasaan klien. Perasaan bagian dari pengalaman yang cukup berisiko baik bagi perawat maupun klien. Selain itu perawat memahaminya dengan ungkapan positif dengan emosional pada keadaan yang berbeda.

Hal ini dapat dilihat pada point pertanyaan penerima ungkapan perasaan positif dan negatif pertanyaan No. 22 yaitu Perawat tidak memperkenalkan diri terhadap klien. Hal tersebut bahwa perawat sudah dapat memberikan interaksi antara perawat dan klien dengan baik secara fisik, emosi dan spiritual akan dipersepsikan oleh penerima pelayanan asuhan keperawatan. Dengan adanya perilaku caring yang baik, maka klien mengungkapkan perasaannya tantang perawat sebagai pemberi pelayanan asuhan keperawatan akan baik. Sehingga kepuasan akan pelayanan asuhan keperawatan juga akan baik. Hal ini sudah dibuktikan di atas, bahwa semakin baik perilaku caring perawat, maka semakin baik pula kepuasan klien.

Sejalan dengan hasil penelitian Arief, Y., Ertawati., \& Laili, D (2016) tentang perilaku caring perawat meningkatkan kepuasan ibu klien. Hasil penelitiannya menunjukkan semua ibu yang memberikan penilaian perilaku caring perawat dalam kategori kurang dapat membentuk kepuasan tingkat sedang. Perilaku caring perawat tingkat sedang dapat membentuk kepuasan yang baik bagi ibu sebesar $67,7 \%$.

Penerimaan ungkapan perasaan positif dan negatif yaitu perawat harus mempersiapkan diri untuk menerima ekspresi perasaan negatif ataupun positif dari klien. Dalam berhubungan dengan klien, perawat harus mampu menunjukkan kesiapan mengambil resiko saat berbagi dengan klien (Potter \& Perry 2012). Hal yang dapat perawat lakukan misalnya memahami setiap ekspresi kekhawatiran klien, cara klien menunjukkan rasa sakitnya, nilai atau budaya yang dimiliki klien berhubungan dengan penyakitnya (Alligood \& Tomey, 2012).

\section{Metode pemecahan masalah pada klien}

Berdasarkan hasil penelitian menunjukkan perilaku caring perawat dilihat dari Metode pemecahan masalah pada klien menilai $47,2 \%$ perilaku caring cukup. Hal tersebut perawat sudah dapat menggunakan metode sistematis dalam pemecahan masalah dengan menumbuhkan kemampuan pengambilan keputusan pada klien dan keluarga.

Hal ini dapat dilihat pada point pertanyaan metode pemecahan masalah pada klien pertanyaan No. 30 yaitu Perawat kurang membantu dalam memahami perasaan klien. Artinya perawat kurang memahami dengan kondisi dan perasaan klien dan perawat hanya melakukan tindakan asuhan keperawatan saja, tanpa perlu adanya pandangan dan pemahaman klien saat ini, serta dapat menumbuhkan sikap carenya terhadap klien, sehingga pengembangan metode yang dilakukan perawat sudah sesuai dengan SPO.

Berpikir kritis adalah suatu proses pengujian yang menitikberatkan pendapat tentang kejadian atau fakta yang mutakhir dan menginterpretasikannya serta mengevaluasi pendapat-pendapat tersebut untuk mendapat kesimpulan tentang adanya perspektif/ pandangan baru (Strader dalam Maryam, Setiawati \& Ekasari, 2008). Berpikir kritis merupakan komponen penting dari perawatan karena perawat selalu dihadapkan dengan situasi yang kompleks, yang menuntut penilaian akurat, pengambilan keputusan yang tepat dan merupakan proses pembelajaran terus menerus.

Morrison (2009) menyatakan bahwa berpikir kritis dapat memberikan pengaruh yang kuat dalam pengambilan keputusan dan pemecahan masalah yang dihadapi oleh manajer perawat setiap hari. Meskipun demikian, ternyata belum semua perawat mempunyai kemampuan berpikir kritis yang baik. Perawat merupakan pemikir kritis yang efektif, sehingga perawat diharapkan dapat melakukan asuhan keperawatan dan mampu memecahkan masalah klinis, baik yang 
bermanfaat bagi klien, perawat, dan lembaga. Karena itu, dalam proses pendidikan hendaknya perawat didorong untuk mengembangkan keterampilan berpikir kritis sehingga dapat mengambil keputusan yang tepat (Wright, Causey, \& Dienemann, 2013).

Kemampuan berpikir kritis dapat ditingkatkan dengan perlakukan. Hasil penelitian Sumartini (2010) menunjukkan bahwa setelah diberikan coaching oleh kepala ruang maka perawat primer yang memiliki kemampuan berpikir kritis baik, jumlahnya lebih banyak dibanding kelmpok kontrol. Hasil pengukuran kemampuan berpikir dipengaruhi oleh berbagai faktor. Berpikir kritis dalam keperawatan sangat dipengaruhi oleh sifat-sifat psikologis, fisiologis dan lingkungan seperti usia, tingkat kepercayaan, bias, keterampilan, stress, kelelahan, dan rekan kerja (Alasad Tabar \& Aburuz, 2015).

Perawat menggunakan metode proses keperawatan sebagai pola pikir dan pendekatan asuhan kepada klien, sehingga akan mengubah gambaran tradisional perawat sebagai "pembantu" dokter. Proses keperawatan adalah proses yang sistematis dan berstruktur. Perawat menerapkan proses keperawatan secara sistematis, membuat keputusan pemecahan masalah secara ilmiah dalam menyelanggarakan pelayanan yang berfokus pada klien (Potter \& Perry 2012).

Perawat harus memahami bahwa setiap individu adalah unik dan situasi dalam menghadapi penyakit berbeda-beda, sehingga dalam menerapkan metode pemecahan masalah perawat harus mampu menyesuaikan teori keperawatan dengan setiap orang dan situasi yang dihadapi (Alligood \& Tomey, 2012).

\section{Proses pengajaran interpersonal}

Berdasarkan hasil penelitian menunjukkan perilaku caring perawat dilihat dari Proses pengajaran interpersonal klien menilai $45,1 \%$ perilaku caring cukup. Hal tersebut berarti perawat sudah dapat mengaplikasikan sikap caren nya kepada klien, dan perawat sudah dapat memberikan informasi kepada klien, serta dapat bertanggung jawab akan kesejahteraan dan kesehatan klien, sehingga tercipta hubungan antara klien-perawat terjalin harmonis. Hal ini dapat dilihat pada point pertanyaan metode pemecahan masalah pada klien pertanyaan No. 33 yaitu Perawat dapat berkomunikasi secara efektif lebih mampu membina hubungan antar diri mereka sendiri dan orang lain, termasuk klien dan keluarga. Artinya kedekatan antara perawat-klien masih kurang dilihat dari komunikasi, baik antar personal klien maupun pada kluarga, berarti sikap komunikasinya masih kurang. Perilaku caring perawat sangat diperlukan dalam membina hubungan agar tercipta hubungan yang baik antara perawat, klien dan keluarga.

Sejalan dengan hasil penelitian Muhlisin, A \& Ichsan, B (2017) tentang aplikasi model konseptual caring dari Jean Watson dalam asuhan keperawatan. Hasil penelitian menunjukkan caring adalah ideal moral dari keperawatan. Manusia akan eksistensi bila dimensi spiritualnya meningkat ditunjukkan dengan penerimaan diri, tingkat kesadaran diri yang tinggi, kekuatan dari dalam diri, intuitif. Caring sebagai esensi dari keperawatan berarti juga pertanggungjawaban hubungan antara perawat-klien, dimana perawat membantu partisipsi klien, membantu memperoleh pengetahuan dan meningkatkan kesehatan.

Perawat memfasilitasi proses belajar mengajar yang didesain untuk memampukan klien memenuhi kebutuhan pribadinya, memberikan asuhan mandiri, menetapkan kebutuhan personal dan memberikan kesempatan untuk kebutuhan personal klien (Watson , 2012). Menekankan bahwa proses keperawatan memiliki langkah-langkah yang sama dengan proses riset ilmiah, karena kedua proses tersebut mencoba untuk menyelesaikan masalah dan menemukan solusi yang terbaik. Lebih lanjut Watson menggambarkan kedua proses tersebut sebagai berikut (tulisan yang dimiringkan menandakan proses riset yang terdapat dalam proses keperawatan). 
Sikap caring berarti perawat bersikap empati, memberi dukungan, simpati serta perlindungan kepada klien. Sikap caring maka dapat memberikan pengalaman yang baik untuk klien. Pendapat ini didukung oleh Wolf, Miller \& Devine (2003) yang menyatakan bahwa kinerja staf perawat termasuk perilaku caring dapat memberikan kontribusi besar terhadap kualitas pengalaman klien selama dilakukan perawatan.

Hal ini merupakan konsep penting yang membedakan antara Caring dan curing. Perawat memberi informasi kepada klien, memfasilitasi proses belajar-mengajar yang diciptakan agar klien dapat meningkatkan kemandiriannya, memenuhi kenutuhan secara mandiri dan memberikan kesempatan untuk pertumbuhan personal klien (Alligood \& Tomey, 2012).

\section{Lingkungan psikologis}

Berdasarkan hasil penelitian menunjukkan perilaku caring perawat dilihat dari Lingkungan psikologis klien menilai 60,6\% perilaku caring cukup. Hal tersebut lingkungan psikologis dipengaruh lingkungan internal dan eksternal klien terhadap kesehatan dan kondisi penyakit klien. Saat ini lingkungan internal klien yaitu mencakup kesejahteraan mental dan spiritual dan kepercayaan sosiokultural. Sedangkan lingkungan eksternal mencakup, kenyamanan, privasi, keselamatan, kebersihan dan lingkungan di sekitar serta membuat kenyamanan klien terhadap kondisi lingkungan yang kondusif dan perawat sudah dapat menjaga privasi klien saat ini, sehingga perawat sudah dapat mensejahterakan kondisi klien.

Hal ini dapat dilihat pada point pertanyaan lingkungan psikologis pertanyaan No. 43 yaitu perawat kurang menjaga ruangan tetap rapi dan bersih. Artinya perawat kurang memperhatikan lingkungan kondisi klien diruangan, seperti kebersihan lingkungan dan alat medis yang tidak dirapihkan kembali, karena beranggapan perawat bukan untuk merapihkannya, tapi pada kenyataannya kerapihan dapat dilakukan oleh siapa saja, termasuk oleh perawat.

Penelitian Suarni, Hadji \& Sjattar (2018) tentang hubungan faktor psikologis dengan kinerja perawat dalam pendokumentasian asuhan keperawatan di Ruang Rawat Inap Rumah Sakit TK II Pelamonia Makassar. Hasil penelitianya menunjukkan bahwa faktor psikologis yang berhubungan dengan motivasi, sikap dan persepsi, kepuasan kerja terhadap kinerja kelompok perawat dalam pendokumentasian asuhan keperawatan.

Faktor psikologis yang berhubungan dengan perilaku caring perawat merupakan proses keperawatan merupakan sebuah cara yang penting untuk mengetahui kemampuan kerja perawat dalam melaksanakan proses pendokumentasian keperawatan dengan menunjungjung sikap care perawat dalam memberikan kenyamanan terhadap klien, sehingga proses keperawatan dari segi lingkungan psikologis sangat penting.

Klien bisa mengalami perubahan baik dari lingkungan internal maupun eksternal, maka perawat harus mengkaji dan memfasilitasi kemampuan klien untuk beradaptasi dengan perubahan fisik, mental dan emosional (Watson, 2012). Perawat harus menyadari lingkungan internal dan eksternal berpengaruh terhadap kondisi sehat-sakit klien. Lingkungan internal meliputi keadaan mental dan spiritual, keadaan sosiokultural, dan kepercayaan individu. Sedangkan lingkungan eksternal ialah kenyamanan, privasi, keamanan, kebersihan, lingkungan yang astetik. Sehingga perawat harus mampu membuat pemulihan suasana fisik dan non fisik serta menciptakan kebersamaan, keindahan, kenyamanan (Alligood \& Tomey, 2012).

Pelayanan keperawatan memberi konstribusi dalam menentukan kualitas pelayanan di rumah sakit. Sehingga setiap upaya untuk meningkatkan kualitas pelayanan rumah sakit harus juga disertai upaya untuk meningkatkan kualitas pelayanan keperawatan salah satunya dengan 
meningkatkan sikap kepedulian terhadap klien dengan cara perawat melakukan sikap "care" terhadap klien nya. Perilaku caring dipengaruhi oleh faktor psikologis yang dapat mempengaruhi caring perawat dalam pendokumentasian asuhan keperawatan di ruang rawat inap. Sikap yang baik adalah sikap dimana ia mau mengerjakan pekerjaan tersebut tanpa terbebani oleh sesuatu hal yang menjadi konflik internal. Ambivalensi sering kali muncul ketika konflik internal psikologis muncul. Perilaku caring perawat sangat dipengaruhi oleh sikap dalam bekerja. Sedangkan sikap seseorang dalam memberikan respon terhadap masalah dipengaruhi oleh kepribadian seseorang. Kepribadian ini dibentuk sejak lahir dan berkembang sampai dewasa. Kepribadian seseorang sulit dirubah karena elemen kepribadian (id, ego,super-ego) dibangun dari hasil bagaimana dia belajar saat dikandungan sampai dewasa. Perilaku ini dapat dirubah dengan meningkatkan pengetahuan dan memahami sikap yang positif dalam mengembangkan sikap caring pada kliennya (Singgih \& Yulia, 2012).

\section{Pemenuhan kebutuhan manusia pada klien}

Berdasarkan hasil penelitian menunjukkan perilaku caring perawat dilihat Pemenuhan kebutuhan manusia pada klien didapatkan $73,2 \%$ perilaku caring baik. Pelayanan kesehatan khususnya di bidang keperawatan dituntut mampu memberikan pelayanan kesehatan yang bermutu dan memberi kepuasan klien serta keluarganya dalam batas standar pelayanan professional.

Hal tersebut sesuai dengan pertanyaan No. 60 yaitu perawat kapan memanggil dokter. Artinya perawat kurang kolaborasi antara perawat dengan dokter, sehingga klien memiliki pandangan yang kurang baik antara perawat dan donker. Secara analisis pada penelitian ini menunjukkan dilihat dari Pemenuhan kebutuhan manusia pada klien didapatkan $73,2 \%$ perilaku caring baik. Hal tersebut jika diketahui dari hasil kuesioner yang paling penting dengan skor tertinggi yaitu tentang perawat memberikan suntikan, infus dll. Perawat memberikan perawatan dan obat tepat waktu, sehingga pemenuhan kebutuhan klien dapat terpenuhi.

Penelitian Purwaningsih, R., Asmaningrum, N \& Wantiyah (2017) tentang hubungan perilaku caring perawat dengan pemenuhan kebutuhan spiritual pada Klien Rawat menunjukkan bahwa nilai $\mathrm{p}=0,011$ dan $\alpha=0,05$ ada hubungan antara perilaku caring perawat dengan pemenuhan kebutuhan spiritual. Perilaku caring perawat dipersepsikan memuaskan $(93,2 \%)$ dan kebutuhan spiritual dirasakan cukup $(75,7 \%)$.

Secara teori oleh Asmuji dan Rohmah (2010) mengungkapkan bahwa dalam pemenuhan kebutuhan dasar klien memerlukan caring perawat, dimana perilaku caring perawat salah satunya sebagai pemberi asuhan keperawatan atau care provider harus dilaksanakan secara komprehensif atau menyeluruh tetapi juga pada tindakan prevetif. Tindakan preventiv dalam upaya menjaga kesehatan yang bisa dilakukan adalah perawat memberi kebutuhan dasar manusia, dimana unsur-unsur yang dibutuhkan manusia dalam mempertahankan keseimbangan fisiologi maupun pskologis seperti makan, minum berpakaian, istirahat, BAK, BAB dan rasa aman dan perlindungan diri.

Watson, (2012) berpendapat bahwa perawat perlu mengenali kebutuhan komprehensif yaitu kebutuhan biofisik, psikososial, psikolofisikal dan interpersonal klien. Pemenuhan kebutuhan yang paling mendasar perlu dicapai sebelum beralih ketingkat selanjutnya. Nutrisi, eliminasi dan ventilasi adalah contoh dari kebutuhan biofisik yang paling rendah, sementara aktivitas dan seksualitas adalah kebutuhan psikofisik yang paling rendah. Pencapaian dan hubungan merupakan kebutuhan psikososial yang tinggi dan aktualisasi diri merupakan kebutuhan interpersonal yang paling tinggi

Diperjelas oleh Alligood \& Tomey, (2012) bahwa memenuhi kebutuhan dasar klien 
meliputi kebutuhan biofisik, psikofisik, psikososial, dan kebutuhan intrapersonal klien dengan sepenuh hati. Pemenuhan kebutuhan yang paling mendasar perlu dicapai sebelum beralih ke tingkat yang selanjutnya. Pemberi pelayanan kesehatan berperan besar dalam pemenuhan kebutuhan klien terutama bagi perawat.

Perawat sebagai tenaga kesehatan yang 24 jam bersama klien penting kiranya tanggap dan peduli terhadap kebutuhan klien, kepedulian dalam pemenuhan kebutuhan klien dapat dilakukan perawat dengan menerapkan perilaku caring. Caring merupakan tindakan konkrit yang muncul dengan sendirinya dari keinginan, maksud, atau komitmen sehingga dengan perawat melakukan perilaku caring dapat meningkatkan dan melindungi kemanusiaan dengan membantu klien menemukan hikmah dari penyakit, penderitaan, nyeri dan keberadaan (Blais, et. al 2013).

\section{Kekuatan eksistensial fenomenologis}

Berdasarkan hasil penelitian menunjukkan perilaku caring perawat dilihat dari Kekuatan eksistensial fenomenologis klien menilai $44,4 \%$ yaitu perilaku caring baik. Hal tersebut perawat menunjukkan perilaku caring dengan Kekuatan eksistensial fenomenologis terhadap klien yang berarti perawat memahami kliennya dengan kondisi saat ini, artinya perawat mengerti dengan keadaan kondisi yang dikeluhkan klien saat ini. Sehingga perawat dapat membantu seseorang untuk memahami kehidupan klien di rumah sakit. Hal ini dapat dilihat pada point pertanyaan Kekuatan eksistensial fenomenologis pertanyaan No. 63 yaitu Perawat membantu klien menjadi lebih baik dan sehat. Artinya perawat sudah membatu klien dalam pemenuhi kebutuhanya, namun belum keseluruhan klien memili pandangan pada perawat tentang kebutuhan manusia terhadap klien.

Penelitian Arrohmah (2017) tentang Gambaran Penerapan 10 Faktor Karatif Caring
Pada Mahasiswa Keperawatan Universitas Diponegoro Yang Telah Menjalani Praktik Klinik Di Rumah Sakit. menunjukkan bahwa mahasiswa keperawatan Universitas Diponegoro sudah dapat menerapkan perilaku caring pada klien selama menjalani praktik klinik di rumah sakit namun belum optimal, dari sepuluh faktor karatif Watson dengan menunjukkan perilaku yang sesuai dengan masing-masing faktor karatif diantaranya Kekuatan eksistensial fenomenologis klien 75\% kurang baik.

Secara teori Hegel (2012) mendefinisikan bahwa fenomenologi berkaitan dengan pengetahuan sebagaimana ia tampak kepada kesadaran, sebuah ilmu yang menggambarkan apa yang dipikirkan, dirasa dan diketahui oleh seseorang dalam kesadaran dan pengalamannya saat itu. Proses tersebut mengantarkan pada perkembangan kesadaran fenomenal melalui sains dan filsafat "menuju pengetahuan yang absolut tentang Yang Absolut".

Menurut Watson, (2012) Kekuatan Eksistensial Fenomenologis merupakan faktor bertujuan agar pertumbuhan diri dan kematangan jiwa klien dapat dicapai. Terkadang klien perlu dihadapkan pada pangalaman/pemikiran yang bersifat proaktif. Tujuannya adalah untuk meningkatkan pemahaman tentang diri sendiri. Diakuinya faktor kreatif ini dalam ilmu keperawatan membantu perawat untuk memahami jalan hidup seseorang dalam menemukan arti kesulitan hidup. Karena adanya irrasional tentang kehidupan, penyakit dan kematian, perawat menggunakan faktor kreatif ini untuk membantu memperoleh kekuatan daya uantuk menghadapi kehidupan atau kematian

Fenomenologis diuraikan sebagai suatu keadaan langsung yang dapat membuat seseorang mengerti tentang situasi yang terjadi. Watson mempertimbangkan bahwa faktor ini memang sulit untuk dimengerti. Namun hal ini akan membawa perawat untuk memahami dirinya sendiri dan orang lain. Sehingga perawat dapat membantu seseorang untuk 
memahami kehidupan dan kematian dengan melibatkan kekuatan spiritual (Alligood \& Tomey, 2012).

Teori Watson dalam Kozier, menjelaskan bahwa praktik caring merupakan pusat keperawatan. Watson menggambarkan caring sebagai dasar dalam kesatuan nilai - nilai kemanusiaan yang universal (kebaikan, kepeduliaan, dan cinta terhadap diri sendiri dan orang lain). Caring digambarkan sebagai moral ideal keperawatan, hal tersebut meliputi keinginan untuk merawat, kesungguhan untuk merawat, dan tindakan merawat (caring).

\section{PENUTUP}

\section{KESIMPULAN}

Sepuluh faktor karatif Watson dengan menunjukkan perilaku yang sesuai dengan masing-masing faktor karatif. Hasil penelitian ini menunjukkan bahwa klien menilai perilaku caring perawat sudah memiliki kategori cukup dan perawat dapat menerapkan perilaku caring pada klien selama menjalani praktik keperawatan di rumah sakit, namun belum optimal. Perawat perlu meningkatkan perilaku caring pada setiap faktor karatif, sehingga diharapkan dapat menjadi dasar dalam membentuk pedoman perilaku caring perawat dan pedoman pemenuhan kebutuhan spiritual padaklien.

\section{SARAN}

Penelitian ini bisa menjadi acuan untuk penelitian selanjutnya. Peneliti selanjutnya dapat mengembangkan dari penelitian ini dengan menilai perilaku caring perawat dengan instrumen yang lainnya, meneliti faktor-faktor yang mempengaruhi pemenuhan kebutuhan klien, dan persepsi klien mengenai perilaku caring dan pemenuhan kebutuhan klien secara kualitatif.

\section{DAFTAR PUSTAKA}

Aiken, 2012. Psychological Testing And Assessment. Ninth Edition. Boston: Allyn And Bacon.

Alasad, Tabar, \& Aburuz, 2015. Fundamental
Of Nursing Standart And Practice Fourt Edition. USA : Dermar Chengage Learning.

Alligood \& Tomey, 2012. Nursing Theorist And Their Work. 6th Edition, St. Louis: Mosby Elsevier, Inc

Arief, Y., Ertawati., \& Laili, D. 2016. Perilaku Caring Perawat Meningkatkan Kepuasan Ibu Klien. Jurnal Ners Vol.4 No. 2: 144-148. D i a k e s: h tt p s: / / e journal.unair.ac.id/JNERS/article/downl oad/5026/3268.

Arrohmah, Munib \& Sarah Ulliya. 2017. Gambaran Penerapan 10 Faktor Karatif Caring Pada Mahasiswa Keperawatan Universitas Diponegoro Yang Telah Menjalani Praktik Klinik Di Rumah Sakit. Skripsi. D i a k e s http://eprints.undip.ac.id/55003/.

Asmuji Dan Rohmah, 2010. Perilaku Perawat Pada Pemenuhan Kebutuhan Manusia. Jakarta.

Barbara \& Pryzby. 2005. Effect Of Nurse Caring Behaviours On Family Stress Responses In Critical Care. Journal Of Intensive And Critical Care Nursing, Volume 21, Issue 1, Feb 2005, Pages 16-23. Diakses: https://www.sciencedirect.com.

Blais, Et Al, 2013. Praktik Keperawatan Profesional. Jakarta: EGC

Cosette, 2008. Sikap Caring Dan Fungsi Profesi. Jakarta

Desima, Riza. 2013. Tingkat Stres Kerja Perawat Dengan Perilaku Caring Perawat. Jurnal Keperawatan, ISSN 2086-3071, Volume 4, Nomor 1. Versi online / URL: http://ejournal.umm.ac.id/index.php/ke perawatan/article/view/2380

Dwidiyanti, 2015. Caring Kunci Sukses Perawatan Mengamalkan Ilmu. Semarang: Hasani.

Fikri, 2017. Perilaku Caring Perawat Pelaksana Di Ruang Gelatik Dan Rajawali RSAU Dr.M.Salamun Bandung. Skripsi. Tidak dipublikasikan. Bandung : STIKes Dharma Husada.

Hanan .A. M; Youssef1, Magda. A.M. Mansour, 
Ibrahim R. A. Ayasreh and Nabeel A. A; Al- Mawajdeh. 2013. A Medical-Surgical Nurse's Perceptions Of Caring Behaviors Among Hospitals In Taif City. Life Science Journal 2013;10(4). Diakses : http://www.lifesciencesite.com.

Hegel, 2012. Philosophy Of History", Yogyakarta: Pustaka Pelajar

Juwariyah, Titik \& Joyo, Nanang. 2014. Hubungan Perilaku Caring Perawat Dengan Tingkat Kepuasan Klien Di Poli VCT RSUD Gambiran Kota Kediri Berdasarkan Teori Watson. Jurnal Ners dan Kebidanan, Volume 1, No. 3, Nopember $2014, h l m .178-183$. Diakses : https://media.neliti.com/.

Kemenkes RI, 2015. Rencana Dan Strategi Kementerian Kesehatan Tahun 20152019.Kemenkes RI. 2015.

Kemenkes RI, Dalam Abdul, 2015. Hubungan Perilaku Caring Perawat Dengan Tingkat Kepuasan Pasien Rawat Inap Rumah Sakit.

Laschinger, Gilbert \& Smith, 2011. Patient Satisfaction As A Nurse-Sensitive Outcome. In D. M. Doran (Ed., Nursing Outcome: The State Of The Science, 2nd Ed. Pp.359. London: Jones\&Bartlett Learning.

Leininger, 2010 Dan Benner, 2010. From Novice

To Expert: Excellence And Power In Nursing Practice, Addison-Wesley, Menlo Park, California

Manurung, S \& Hutasoit, M 2013. Persepsi Pasien Terhadap Perilaku Caring Perawat di Ruang Rawat Inap Rumah Sakit. Jurnal Kesehatan Masyarakat Nasional Vol. 8, No. 3, Oktober 2013.

Marriner \& Tomey, 2012. Nursing Theorist And Their Work. Copy Right 2012, Mosby Inc Mcdaniel Dalam Watson, Jean. 2012. Assessing And Measuring Caring In Nursing And Health Science 2nd Edition. New York : Springer Publishing Company Inc.

Morrison \& Burnard, 2009. Caring \& Communication $\mathrm{Hubungan}$
Interpersonal Dalam Keperawatan. Jakarta: EGC.

Muhlisin, A \& Ichsan, B. 2017. Aplikasi Model Konseptual Caring Dari Jean Watson Dalam Asuhan Keperawatan. Berita Ilmu Keperawatan ISSN 1979-2697, Vol . 1 No.3, September 2008 :147-150. Diakses: http://journals.ums.ac.id/index.php/BIK/ article/download/3752/2421.

Novieastari, 2012 Dalam Prayuda 2014. Pengaruh Penerapan Perilaku Caring Perawat Anestesi Pada. Pelayanan Pre Anestesi Di RSUD Kebumen. Poltekkes. Yogyakarta.

Nursalam, 2014. Konsep Dan Penerapan Metodologi Penelitian Ilmu Keperawatan. Edisi 2. Jakarta : Salemba Medika

Potter \& Perry, 2012. Buku Ajar Fundamental Keperawatan: Konsep, Proses Dan Praktek. Volume II. Jakarta: EGC.

Potter \& Perry, 2013. Buku Ajar Fundamental Keperawatan: Konsep, Proses Dan Praktek. Volume II. Edisi Revisi. Jakarta: EGC.

Rego, Godinho, Mcqueen, 2012. Emotional Intelligence In Nursing Work. Journal of Advanced Nursing, 47(1), 101-108. Diakses: https://www.ncbi.nlm.nih.gov/pubmed/ 15186473.

Singgih \& Yulia, 2012. Psikologi Keperawatan. Libri: Jakarta.

Sitorus, 2013. Manajemen Keperawatan: Manajemen Keperawatan Di Ruang Rawat, Sagung Seto, Cetakan I, Jakarta.

Suarni ; Hadji, V; \& Sjattar, E. 2018. Hubungan Faktor Psikologis Dengan Kinerja Perawat Dalam Pendokumentasian Asuhan Keperawatan Di Ruang Rawat Inap Rumah Sakit TK II Pelamonia Makassar. Manuskrip Tesis. Diakses : pasca.unhas.ac.id/jurnal/

Suliano, M \& Sari, R. 2016. Hubungan Perilaku Caring Perawat Dengan Keyakinan Dan Harapan Klien Kanker Di Rumah Sakit. Media Medika Muda.Volume 1, Nomor 1, Januari - April 2016. Diakses : 
https://ejournal2.undip.ac.id.

Sumartini, B.T. 2010. Pengaruh Penerapan Panduan Coaching Kepala Ruang terhadap Kemampuan Berfikir Kritis dan Pengambilan Keputusan Perawat Primer dalam Proses Keperawatan di Ruang Rawat Inap PKSC. Tesis. Tidak dipublikasikan. FIKUI.

Suryantini, P., Fahmi Nur, 2014. Hubungan Perilaku Caring Perawat Dengan Kepuasan Pasien Di Ruang Rawat Inap Interna Gunung Jati Dan Gunung Giri RSI. Sakinah Mojokerto. Jurnal Keperawatan Sehat, Volume 11, No. 2. Diakses: ejournal.stikes-ppni.ac.id.

Tiara \& Lestari. 2013. Hubungan Antara Caring Perawat Dengan Tingkat Kepuasan Klien Rawat Inap Di Rumah Sakit Umum Daerah Pringsewu Lampung. Jurnal Keperawatan, Vol IX, No. 2, Oktober 2013. ISSN 1907-0357. Hal 115-119. Diakses : http://ejurnal.poltekkestjk.ac.id.

Tumanggor. Hubungan Perilaku Caring Perawat Dengan Tingkat Kecemasan
Pasien Kankar Payudara Di RSUP H.Adam Malik Medan. Skripsi. Diakses: http://repository.usu.ac.id/handle/12345 $6789 / 45064$.

Wardhono, 2012. Menuju Keperawatan Profesional. Semarang: Akper Depkes.

Watson, 2012. Assessing And Measuring Caring In Nursing And Health Science 2nd Edition. New York : Springer Publishing Company Inc.

Wolf, Miller \& Devine, 2003. Relationship Nurse Caring And Patient Satisfaction In Patient Undergoing Invasive Cardiac Procedures. Research for Practice. MEDSURG

Wright, Causey, \& Dienemann, 2013. Patient Satisfaction With Nursing Care In An Urban And Suburban Emergency Department. JONA: The Journal of Nursing Administration. 43(10):502-508, $\begin{array}{llllll}O C & \text { C } & 2 & 0 & 1 & 3\end{array}$. D O I : 10.1097/NNA.0b013e3182a3e821. d $\mathrm{i}$ a $\mathrm{k} \quad \mathrm{s}$ e $\mathrm{s}$ : https://www.ncbi.nlm.nih.gov/pubmed/ 24061582. 